\title{
CSR as a Driver where ESG Performance will Ultimately Matter*
}

\author{
Andrea Cincinnati Cini ${ }^{* *}$, ChiaraRicci ${ }^{* * *}$
}

\begin{abstract}
Despite the clear evidence and vast research conducted both in Europe and America, little is known about the correlation between CSR and ESG performance metrics. The risk reporting and analysis are integrally tied to heightening efficiency, yet when it comes to risk reporting through ESG perspective the evidence is fragmentary and approximate. Starting from the question whether corporate social responsibility has a positive impact on firm long-term value, we have therefore explored how fundamental is for a company being capable of measuring its extrafinancial performance. Using a cross section of resources, we examine how essential is to evaluate firms performance through ESG reporting and why capital has started to flow towards high-ESG firms and in turn more sustainable companies. Given that social responsible companies are frequently estimated as more economically successful, we point out that being just CSR oriented is not an option anymore, but imperative. The trend is clear and the market has answered the question of whether ESG risk reporting is valuable or not.
\end{abstract}

Keyword: Sustainability; ESG-Environmental Social Governance; Coffee Market; Lavazza Foundation; Supply Chain Empowerment; Family Business; Global Markets

\section{ESG - Environmental Social and Governance}

In the recent years, increasing growth in the demand for Corporate Social Responsibility (hereafter CSR) practices has been witnessed. As a consequence, there has been a significant increase in the number of industry leaders or consultancy companies which supply CSR research, Environmental Social and Governance (hereafter ESG) indexes, expert advice and ratings. However, the concept of CSR has a quite long and vast literature (Mosca \& Civera, 2017) and its origins can be found since from the fifties both in United States (US) and in Europe (Carrol 1999). Indeed, the renewed 'ecological conscience' has exceeded national frontiers thanks to a 'stretching of social, political and economic activities across political frontiers'

\footnotetext{
* Invited Article

${ }^{* *}$ Senior Advisor, Integrated Accounting Services, Deloitte \& Touche S.p.A.

(a.cincinnaticini@deloitte.it)

**** ESG Analyst \& Research, Integrate S.r.l.( c.ricci@integrate-esg.com)
} 
(Held \& McGrew, 2007) and, in turn, it has required a broader approach (Brondoni \& Mosca, 2017).

This improved awareness has led to the recognition of the resource's limitation and of the crucial anthropomorphic aspects of the current environmental and social challenges (Blower, 1997). Against environmental instability, the need to protect prime components such as air, water, soil, human rights and work conditions with legal means through a global and combined impact has become imperative (Lambin, 2009). As a result, climate change and its inner meaning has become a problem for all countries: from the political to the economic level, from the cultural to the social field (Salvioni \& Bosetti, 2014).

The following essay will firstly briefly present where the CSR discipline stems from and why it is clear that who implements CSR practices would gain a competitive advantage in the market. Secondly, the significance of ESG performance metrics will be outlined in order to make explicit the relationship with the CSR topics. Lastly, it will also be argued that European Union (EU) has acquired the leading role in addressing environmental challenges by involving the finance market towards social responsible investment.

This paper aims to evidence that firms have to seriously consider the idea of not just practicing CSR within their strategy, but also of measuring it through an ESG analysis. To conclude, it will be pointed out that facing the demand of ESG reporting would become compulsory and not an option anymore.

\section{CSR Overview}

CSR literature is quite comprehensive because it has a long and multi-faced history. Since it embraces various disciplines ranging from economics to sociology, formal writings on social responsibility are easily traced, especially in the past 50 years (Carroll, 1990). Rather than to review all that has been said by anyone on the subject, few definitional constructs will be presented.

First and foremost, Harrison and Freeman (1999) argue that company's board must take into account several actors at stake, namely stakeholders. If they would focus their attention only on the shareholders needs, their financial performance will ultimately be damaged. To this extent, those stakeholders in possess of power, legitimacy and urgency must be listened by the management, which in turn has to successfully balance their competitive demands.

Secondly, in this context researchers start focusing on the so-called 'triple bottom line' (TBL). Elkington (1994) proposes a new accounting framework that embraces three different dimensions of performance: social, environmental and financial. This system differs from the traditional one because it introduces new ways to assign a proper mean of measurement to the social and ecological dimensions. Moreover, under these circumstances it is feasible to build long-term relationships both inside and outside the company with different stakeholders. This important step might lead firms to a win-win situation and give to all the parties at stake the opportunity to create triple bottom line politics (Elkington 1998).

Lastly, a similar concept can be found in the Brundtland Report (1987), which takes the CSR definition slightly further. Indeed, the Report serves as a pivotal marker since it contributes to the explanation of sustainable development as 'the ability to meet the needs of the present without compromising the ability of future generations to meet their needs' (Sneddon et al., 2006). 


\begin{abstract}
$\square$ Similarly, the European Federation of Financial Analysts Societies (EFFAS) points out that 'being sustainable means that companies actively pursue goals such as responsible use of natural resources both in their own operations and the operations of their respective clients, as well as respecting social rights in their markets of operation and those markets where their products and services are in use and being accountable to providers of equity and debt capital' (EFFAS 2010).
\end{abstract}

In conclusion, the naturally development and application of the before mentioned fundamentals result in what businesses call the shared value. In this degree, Porter and Kramer (2011) highlight the necessity to pull all the available strings to create shared value by pursuing the intersection between society and firm's performance. Even though first steps have been taken, a deeper understanding of social needs, a productive collaboration across profit/non- profit boundaries and more sustainable governance still have to be structured.

In the meantime, numerous studies have been published to explicitly show the relationship between CSR and business success. Despite this assumption, it is still not widely recognised that a socially and environmentally responsible management allows firms to increase corporate operating income (Griffin \& Mahon, 1997). However, companies have made great progresses developing CSR initiatives and playing a leading role in addressing a wide range of either social or climate changerelated issues. They, therefore, start tracking operational changes and improvements by linking specific KPIs to their CSR projects (Bonini et al., 2009). Thanks to them, it is possible to evaluate how environmental, social and governance programs can create shared value. Specifically, four main areas have been identified: business growth, returns on capital, risk management and quality management.

The former explains that environmental, social and governance programs allow companies to better build new relationships with local-based organizations and acquire a greater understanding of what new customers concerns might be. As a consequence, translating ESG issues into company's products and service portfolio allows the company to access new markets, establish its presence and develop innovative products and so to enhance its long-term viability.

Another aspect that should be considered is the return on capital. While still few experts consider CSR programs expensive, the link between environmental goals and operational efficiency is strong. Take for example the employment of resources to either reduce energy costs through energy efficiency or reduce input cost through packaging initiatives and process improvements.

An additional explanation can be found in the risk management. Research highlights how company's behaviour shifts from programs' implementation to mitigate risks to their active management by taking stand on important issues, such as corruptions, labour practices and use of limited resources. Indeed, this attitude benefits the company reputation and helps it to build solid relationships with its stakeholders.

To sum up, even if social and environmental factors are identified as higher costs and as a side effects less responsible companies might benefit economically from the ones that instead invest in CRS programs, problems as material consumption, waste and pollution actually represent an opportunity to lower costs, manage risks and develop trans-disciplinary skills and capabilities among employees, for instance in prevention and eco-efficiency (Hart \& Milstein, 2003). 
In the latest years, more and more companies have acknowledged the consistent connection between social progress and their own success as interdependent. Moreover, firm has inevitably faced the reality, where 'no company operates in isolation; each exists in an ecosystem where societal conditions may curtail its markets and restrict the productivity of its suppliers and distributors' (Kramer \& Pfitzer, 2016: 4). In this context, it is undeniable that international organizations and government policies play a crucial role in firm's behaviour. Under these circumstances, companies have started to view themselves as part of a broader economic system and, consequently, to disclose their CSR practices through a measurement of their environmental, social and governance performance. Furthermore, since global reporting standards guidelines, such as GRI, have become the de facto international reporting standard, firms can now provide comprehensive information on their both environmental and social performance, report their specific ESG data and outline the associated impact (Jones et al., 2015). In conclusion, the change here is clear, company have been asked to provide quantitative ESG metrics and specific goals instead of offering qualitative descriptions of their performance.

The reasons behind the decision to report ESG performance are various. While a growing number of companies understand the competitive advantage that can be gained, others adopt a reactive approach. The main signs of this latter trend are based on the idea that firms start reporting either as a public-relation exercise or because their stakeholders initiate questioning them on their specific ESG behaviour. Moreover, when the ESG report is used to communicate corporate information through the marketing department the significance of reporting is by no means useful. In fact, since every company to varying degrees has a rough idea of what ESG responsibilities are, ESG and CSR reporting needs to be connected to the core business strategy and the internal company measuring system. This means that firms have to identify specific fields of ESG activity, monitor objectives' achievement through a detailed and uniformed KPI's structure within a regulated process that collects data, manages data transmission and its aggregation. Once this is in place and board and top management are involved, ESG reporting becomes a critical step toward a competitive enterprise. These actions lead to a functional management of company's performance, because it allows to identify issues and to prioritize them, set targets and track both improvements and losses (MacLean \& Rebernak, 2007). Ultimately, it will allow the definition of code of conduct, environmental management guidelines as well as health and safety policies. In this degree, a brilliant case is made by the FTSE MIB listed company Prysmian which has started to link variable management compensation to sustainability KPIs (see Prysmian Group, Report on the Remuneration of the Board of Directors 2018). Here, the variable remuneration is paid when performances exceed the target planned, which has to include the year-on-year sustainability rating index performance. Thus, other listed companies such as Unicredit, Enel and Terna have in place sustainability committees or steering committees called to verify the adequacy and effectiveness of sustainability practices in line with the objectives of the approved Strategic Plans.

Another aspect that should be pointed out is that CSR practices have a strong impact on ESG factors as intangibles on expected future earnings and risk profile. This is why extra- financial performance influences companies' share price. The Social Responsible Investment (SRI) concept involves the investment process where investment decision-making combines financial goals and ESG considerations (Renneboog, 2008). Even though this phenomenon is still a niche segment of market 
value, ESG stock has showed to achieve actual earnings announcement above earnings estimates and analysts' forecast (Hassel \& Semenova, 2013). Indeed, the integration of ESG externalities, which represents impacts on economic decisions, may offset shortcomings thanks to the recognition of expenses for the period they relate, not when later cash flows for actual mitigation take place. That is because sustainability accounting mixes existing accounting information with the one related to ESG risks, in terms of extra revenue or avoided costs. As matter of fact, as the event study analysis conducted by Unicredit in 2010, capitalised ESG issue can affect stock valuations by $1.7 \%$ on average (Berger, 2010).

To this extent, many initiatives have been undertaken, for instance the UN Principle for Responsible Investment (PRI) takes a significance role in fostering the involvement of ESG issues in the investment decision-making, strengthening the idea ESG factors actually have an impact on risk management and earnings forecast's accuracy (Hassel \& Semenova, 2013).

As a direct reaction to these changes (Brondoni, 2014), there has been a growth in the demand for ratings of CSR (so called Sustainability Ratings). These ratings result in the increased number of groups that supply CSR ratings to investors and consumers, becoming the main way to communicate ESG firm's performance (Màrquez \& Fombrun, 2005). Although rating agencies' aim appears clear, there are few downsides that should be considered. The rating's marketplace conduct is confusing due to a proliferation of players and ways to assess the ESG company performance. Despite the fact that the main agencies in place are carefully specialized to provide a scrupulous evaluation of company 'socially responsible' behaviour and to which extent its activities are connected with its risks, profitability, sector and production, it is still not clear which criteria are applied during the evaluation process (Màrquez \& Fombrun, 2005). To conclude, ESG rating agencies have an incredible power on company's reputation, so they must provide a valid and reliable result.

This environment leads to a proliferation of several actors but among them only one stands up. European Union has demonstrated to proactively lead the change, especially when it comes to talk about the need to finance a sustainable growth. Stemming from the 17 Sustainable Development Goals (SDGs) and Paris Agreement's outcome, the European Commission has turned its agenda toward a resilience climate change aim in order to assure long-term competitiveness of the EU economy. As a consequence, reorienting private capitals to more sustainable investment has become vital. In order to satisfy this demand, the UE Commission appointed a High-Level Expert Group (HLEG) with the main objective to report on the current financial system and to make recommendations. Following HLEG recommendations, the EU Commission at the beginning of March 2018 set out the EU Action Plan for Sustainable Finance, in which 10 key points are highlighted.

On top of all, an unmistakable taxonomy must be produced to reach a shared understanding of what being sustainable means. After that, a step-by-step approach will allow the EU sustainability taxonomy to be integrated in the EU legislation. Additionally, this will lay the foundation for the following achievements, such as the definition of EU standards and labels, and the mobilization of private capitals for sustainable infrastructure investment.

Another important step must be made toward more sustainable considerations in the financial advise. It contributes thus to claim investment firms and insurance distributors to take into account client's preference on ESG factors when proposing financial products. To this extent, sustainability benchmarks must be provided because the traditional ones are inadequate due to a lack of transparency and 
reliability. In this direction, J.P. Morgan recently announces a new suite of global fixed income indices, which will ultimately integrate ESG factors in a composite benchmark.

As it has been mentioned before, market research providers and rating agencies have come forward and proposed themselves as the best actors to assess ESG performance. Unfortunately, the hole created by the absence of an accepted market standards and a lack of transparency on the criteria used to assess needs to be fulfilled. That is why the HLEG recommends ESMA to assess credit rating practices by keeping in mind ESG information and schedules a comprehensive study to analyse sustainability ratings in place and what their methodologies are.

An additional high-priority point is the involvement of banks, insurance companies and pension funds as they represent a crucial channel of liquidity for investments. Besides their exposure to unsustainable economic development, for instance climate change-related risks, the HLEG suggests to define more appropriate capital requirements. Take for example, the idea of linking energy efficiency savings and mortgage loan performance (European Commission 2018).

In conclusion, public concerns to preserve the sustainability of EU development are reflected in a rapid expansion of sustainability guidelines and regulations set out by the EU institutions. Indeed, a clear sign has been made through the greater emphasis posed by the European 2020 Strategy, the 17 Sustainable Development Goals (SDGs) and the Paris Agreement's outcome. This trans-disciplinary approach has involved different sectors, even the financial one. For this reason, EU made its position evident: it is not possible to reach environmental and social goals without the financial sector being mainly involved.

\section{Conclusion}

While the Paris agreement have been ratified by more than 110 countries, the situation remains critical. The last 16 years were among the 17 warmest on record. So, to limit the risk of catastrophic climate change, it is necessary to keep global warming to within $2^{\circ} \mathrm{C}$ and to do so emissions must be reduced by 40 to $70 \%$ by 2050. In order to achieve this aim, all sectors of

society must collaborate to create an inclusive vision for the future. Moreover, politically approaching climate change and the implementing of sustainable financial frameworks must still be considered very much a long-term objectives.

As demonstrated by the latest Global Risks Report 2017, global risks have evolved in new issues. While some of them were reclassified as water crises and income disparity, others have been introduced. For instance, more attention has been paid in climate change mitigation failure, extreme weather conditions and profound social instability. To sum up, the report findings illustrate three main trends: inequality and polarization, environment-related risks, and new resilience challenges due to the coming Fourth Industrial Revolution (World Economic Forum, 2017).

Moreover, in terms of the electoral results, 2016 has been surprising. It is unknown how this result will play out in terms of political decisions or affect global risk landscapes. What is certain is that climate change will influence politics in a way or in another.

Having said that, as long as CSR remains a tactic adds-on to management decisions or a sort of way to give a slightly more humane face to business, CSR will continue being a compliance exercise and so pointless. Withal, if companies start to better 
manage their ESG performance, they will be able to promptly identify future legislative initiatives and shape opinion processes. Anticipating such developments will grant them the position as one of the ESG pioneers.

As things stand, there is still scope of manoeuvre for all the actors in place. First, from a European perspective new projects have been launched. The mentioned 'Action plan: financing sustainable growth' highlights this point. It represents the change to promote a real change in linking ESG performance score to investing decisions. Therefore, it aims to re-orient private capital in a financial system where transparency and long-termism are fostered. Secondly, many individuals, bottom-up organizations and especially businesses have stepped out their comfort zone. According to the recent research conducted by MSCI, companies with strong management of industry-specific ESG risk better perform than the ones that poorly manage ESG risk. Indeed, the results of the research have shown that companies with high returns, high margins and financial efficiency demonstrate the best ESG ratings and that environmental and social pillars make the real difference (MSCI, 2018).

In conclusion, the trend is clear and the market has started answering the question of whether on-going mainstreaming ESG information will reflect ESG-related capital flows. Social and environmental capital dynamics will not wait neither political institutions nor CSR laggards to affect our lives, so it is better for all to be responsibly engaged.

\section{Bibliography}

Berger, P.Y. (2010). The Halo's Creed, Unicredit ESG Research, London. Available at: http://www.longfinance.net/images/reports/pdf/unicredit_esg_2010.pdf, accessed 14 April 2018.

Blowers, A. (1997). Environmental Policy: Ecological Modernisation or Risk Society?, Urban studies, 34, (5-6), $845-871$.

https://doi.org/10.1080/0042098975853

Brondoni, S. M. (2014). Global Capitalism and Sustainable Growth. From Global Products to Network

Globalisation, Symphonya. Emerging Issues in Management, 1, 10-31.

http://dx.doi.org/10.4468/2014.1.02brondoni

Brondoni, S.M., \& Mosca F. (2017). Ouverture de 'Integrated Corporate Social Responsibility', Symphonya. Emerging Issues in Management (www.unimib.it/symphonya), (1), 1 - 6.

http://dx.doi.org/10.4468/2017.1.01ouverture

Carroll, A.B. (1999). Corporate Social Responsibility. Evolution of a Definitional Construct, Business \& Society, 28, (3), $268-295$.

https://doi.org/10.1177/000765039903800303

DVFA, EFFAS. (2010). KPIs for ESG: Key Performance Indicators for Environmental, Social and Governance Issues - a Guideline for the Integration of ESG into Financial Analysis and Corporate Valuation (Version 3.0). DVFA-EFFAS: Frankfurt.

Elkington, J. (1994). Towards the Sustainable Corporation: Win-Win-Win Business Strategies for Sustainable Development, California Management Review, 36, 90 - 100.

https://doi.org/10.2307/41165746

Elkington, J. (1998). Partnerships from Cannibals with Forks: The Triple Bottom Line of 21stCentury Business, Environmental quality management, 8, 37 - 51.

https://doi.org/10.1002/tqem.3310080106

European Commission (2018). Action Plan: Financing Sustainable Growth. Brussels: European Union, 8 March 2018.

Griffin, J.J., \& Mahon, J.F. (1997). The Corporate Social Performance and Corporate Financial Performance Debate: Twenty-Five Years of Incomparable Research, Business \& Society, 36, 5 - 31. 
https://doi.org/10.1177/000765039703600102

Harrison, J.S., \& Freeman, R.E. (1999). Stakeholders, Social Responsibility, and Performance: Empirical Evidence and Theoretical Perspectives, Academy of Management Journal, 42, (5), 479 485.

https://doi.org/10.5465/256971

Hart, S.L., \& Milstein M.B. (2003). Creating Sustainable Value, Academy of management executive, $17,(2), 56-67$.

https://doi.org/10.5465/ame.2003.10025194

Held, D., \& McGrew, A. (2007). Globalisation / Anti-Globalisation: Beyond the Great Divide, Cambridge, UK. Polity Press.

Jones, P., Comfort, D., \& Hillier, D. (2015). Managing Materiality: A Preliminary Examination of the Adoption of the New GRI G4 Guidelines on Materiality within the Business Community, Journal of Public Affairs, 16, (3), 222 - 230.

https://doi.org/10.1002/pa.1586

Kramer, M.R. \& Pfitzer, M.R. (2016). The Ecosystem of Shared Value, Harvard Business Review, 94, (10), 1-11.

Lambin, J.J. (2009). Capitalism and Sustainable Development. Symphonya. Emerging Issues in

Management (www.unimib.it/symphonya), (2), 3 - 9. http://dx.doi.org/10.4468/2009.2.02lambin

MacLean, R., Rebernak, K. (2007). Closing The Credibility Gap: The Challenges of Corporate Responsibility Reporting, Environmental Quality Management, 16, 1 - 6.

https://doi.org/10.1002/tqem.20137

Márquez, A., \& Fombrun, C.J. (2005). Measuring Corporate Social Responsibility, Corporate Reputation Review, 7, (4), 304 - 308.

https://doi.org/10.1057/palgrave.crr.1540228

Mosca, F., \& Civera, C. (2017). The Evolution of CSR: An Integrated Approach, Symphonya.

Emerging Issues in Management (www.unimib.it/symphonya), (1), 16 - 35.

http://dx.doi.org/10.4468/2017.1.03mosca.civera

Porter, M.E., \& Kramer, M.R. (2011). Creating shared value, Harvard Business Review, 89, (1), 62 67.

Prysmian Group (2018). Report on the Remuneration of the Board of Directors, 1 - 43.

Renneboog, L., Horst, J.T., \& Zhang, C. (2008). Socially Responsible Investments: Institutional Aspects, Performance And Profitability, The Academy of Management Journal, 40, (3), 534 - 559. http://dx.doi.org/10.1016/j.jbankfin.2007.12.039

Salvioni D. M., \& Bosetti L. (2014). Sustainable Development and Corporate Communication in Global Markets, Symphonya. Emerging Issues in Management (symphonya.unimib.it), (1), 1 - 19. http://dx.doi.org/10.4468/2014.1.03salvioni.bosetti

Sneddon, C., Howarth, R.B., \& Norgaard, R.B. (2006). Sustainable Development in a PostBrundtland World, Ecological Economics, 57, 253 - 268.

https://doi.org/10.1016/j.ecolecon.2005.04.013 